\title{
KARATERISTIK PASIEN HIPERTENSI RAWAT INAP DI RUMAH SAKIT ABDUL WAHAB SJAHRANIE SAMARINDA
}

\author{
Tiurliana Octavia Simarmata ${ }^{1, *}$, Wisnu Cahyo Prabowo ${ }^{1}$, Muhammad Amir ${ }^{2}$ \\ ${ }^{1}$ Laboratorium Penelitian dan Pengembangan Kefarmasian "Farmaka Tropis", \\ Fakultas Farmasi, Universitas Mulawarman, Samarinda \\ *Email :octavia_simarmata@yahoo.com \\ ${ }^{2}$ Program Studi Pendidikan Kimia, Fakultas Keguruan dan Ilmu Pendidikan, \\ Universitas Mulawarman, Samarinda
}

\begin{abstract}
The purpose of this research is to know about charateristic in hypertension patients at Abdul Wahab Sjahranie Hospital Samarinda. This study was done by using the retrospective method to determine characteristic hypertensive in hospitalized patients with consecutive sampling. This study used medical record patient in January-July 2014 periode. The sample was determined in inclusive criteria that 65 medical record. Data was removed to worksheet. The characteristic was analysed by age, sex, case story and complication. The most case of Hypertensive was found in ranged-age $>40$ years old that men and women. Hypertensive was found with case story and complication. That was indicated that case story can be a risk of hypertensive. Complication is condition of patient that disrupt the medication. The result showed that this research found the characteristic of hypertensive patient the most in ranged age 41-60 (58,46\%), sex female (30,76\%), have hypertensive case story (48,57\%) and with complication $(36,9 \%)$.
\end{abstract}

\begin{abstract}
ABSTRAK
Tujuan penelitian ini adalah untuk mengetahui karateristik pasien hipertensi di Rumah Sakit Abdul Wahab Sjahranie Kota Samarinda. Penelitian bersifat deskriptif, pengambilan data dilakukan secara retrospektif pada pasien hipertensi yang memenuhi kriteria inklusi dengan metode consecutive sampling. Data diambil pada periode bulan Januari-Juli 2014 melalui rekam medik. Sampel ditentukan berdasarkan kriteria inklusi sebanyak 65 rekam medik. Data pasien dipindahkan dalam lembar kerja penelitian. Karateristik pasien dianalisis berdasarkan usia, jenis kelamin, riwayat penyakit dan penyakit penyerta. Hipertensi banyak terjadi pada usia $>40$ tahun baik laki-laki maupun perempuan. Pasien hipertensi lebih banyak memiliki riwayat penyakit dan penyakit penyerta. Hal ini menunjukkan bahwa riwayat penyakit memiliki resiko terhadap terjadinya hipertensi. Penyakit penyerta
\end{abstract}


merupakan kondisi pasien yang dapat mengganggu dalam terapi pengobatan. Hasil penelitian menunjukkan bahwa penderita hipertensi paling banyak diderita oleh pasien berusia 41-60 tahun $(58,46 \%)$, jenis kelamin perempuan $(30,76 \%)$, memiliki riwayat penyakit hipertensi $(48,57 \%)$ dan pasien dengan penyakit penyerta $(36,9 \%)$.

\section{Kata Kunci : Hipertensi, karateristik pasien}

\section{PENDAHULUAN}

Hipertensi didefenisikan oleh Joint National Committee on Detection, Evaluation and Treatment of High Blood Preasure (JNC 7) sebagai tekanan yang lebih tinggi dari 140/90 mmHg. Hipertensi merupakan salah satu masalah kesehatan masyarakat yang banyak diderita di dunia dan mendapat perhatian di kalangan masyarakat akibat dampak yang ditimbulkan [1].

Berdasarkan data WHO, prevalensi hipertensi di dunia sekitar 600 juta orang dan kematian akibat hipertensi sekitar 7,12 juta orang. Riset Dasar Kesehatan tahun 2007 menunjukkan bahwa prevalensi hipertensi yaitu sebesar 31,7\% dari penduduk dewasa. Riset Dasar Kesehatan tahun 2013 menunjukkan prevalensi hipertensi di Indonesia berdasarkan hasil pengukuran pada umur $\geq 18$ tahun sebesar $36,8 \%$ [2].

Riset Dasar Kesehatan tahun 2007 menunjukkan bahwa prevalensi hipertensi yaitu sebesar 31,7\% dari penduduk dewasa. Riset Dasar Kesehatan tahun 2013 menunjukkan prevalensi hipertensi di Indonesia berdasarkan hasil pengukuran pada umur $\geq 18$ tahun sebesar 25,8\%, tertinggi di Bangka Belitung (30,9\%), diikuti Kalimantan Selatan (30,8\%) dan Kalimantan Timur (29,6\%) [3].

Berdasarkan hal ini, untuk memaksimalkan terapi pasien salah satu upaya yang dapat dilakukan yakni menganalisis karateristik pasien hipertensi di Rumah Sakit Abdul Wahab Sjahranie.

\section{METODE PENELITIAN}

\section{Bahan}

Kartu rekam medik pasien hipertensi yang memenuhi kriteria inklusi, yang diperoleh dari 100 pasien pada Rumah Sakit Abdul Wahab Sjahranie Samarinda, Kalimantan Timur.

\section{Peralatan}

Lembar kerja pemindahan data dan alat tulis.

\section{Prosedur}

Penelitian diawali dengan observasi pasien hipertensi, kemudian pengambilan sampel dilakukan dengan teknik random sampling dengan metode 
consecutive sampling. Sampel ditentukan dari populasi pasien yang memenuhi kriteria inklusi. Kriteria inklusi sampel yaitu:

a. Pasien hipertensi rawat inap di Rumah Sakit Abdul Wahab Sjahranie

b. Pasien hipertensi dengan atau tanpa penyakit penyerta

c. Pasien yang memiliki data rekam medik yang lengkap

d. Pasien tidak dalam keadaan hamil

Penelitian ini dilakukan dengan pengambilan data secara retrospektif. Pengumpulan data dilakukan dengan mencatat beberapa parameter meliputi nomor rekam medik, umur, jenis kelamin, diagnosa, keluhan, riwayat penyakit dan penyakit penyerta. Data penelitian dianalisis secara deskriptif dan dihitung dengan perhitungan :

$\%$ Karateristik $=\mathrm{F} / \mathrm{T} \times 100 \%$

Keterangan :

$\mathrm{F}=$ Frekuensi kejadian

$\mathrm{T}=$ Total populasi sampel

\section{HASIL DAN PEMBAHASAN}

Penelitian ini dilakukan di rumah sakit A. W. Sjahranie. Populasi penelitian diperoleh 139 orang dan 100 orang yang memiliki data rekam medik yang lengkap. Sampel penelitian yang masuk dalam kriteria inklusi sebanyak 65 orang dan dianalisis karateristiknya berdasarkan usia, jenis kelamin, penyakit penyerta dan riwayat penyakit. Gambaran karateristik pasien hipertensi berdasarkan jenis kelamin dan usia (gambar 1).

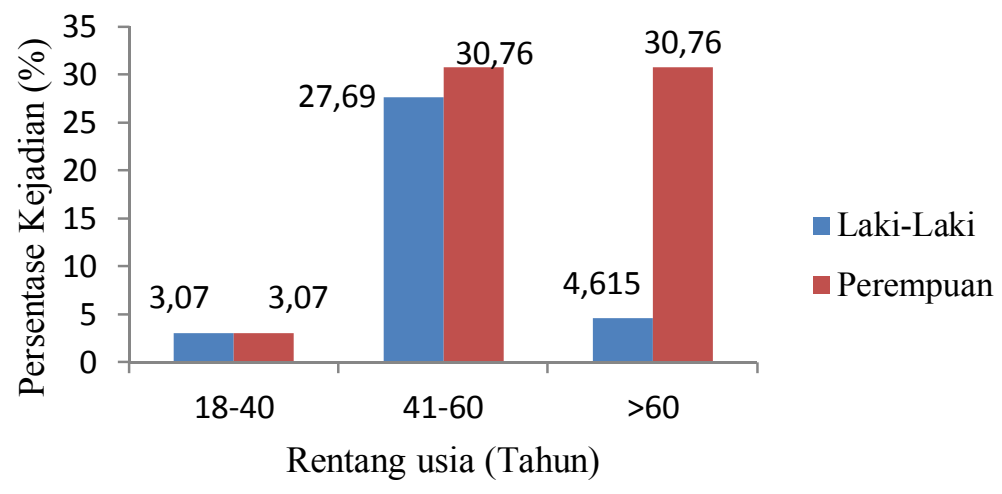

Gambar 1. Pasien Hipertensi berdasarkan Jenis Kelamin dan Usia

Berdasarkan gambar 1, diketahui bahwa pasien hipertensi dengan usia 41 hingga 60 tahun memiliki prevalensi yang lebih banyak dibandingkan usia muda dan jenis kelamin perempuan lebih banyak dibandingkan laki-laki. Hal ini disebabkan karena perempuan lebih mudah stres dibandingkan dengan laki-laki [4]. Selain itu, wanita berumur diatas 40 tahun akan mengalami menopause yang menyebabkan hormon esterogen menurun. Penurunan hormon esterogen dapat meningkatkan tekanan darah karena esterogen berperan melawan hipertensi melalui penghambatan jalur vasokontriktor oleh sistem saraf simpatik dan angiotensin [5]. 

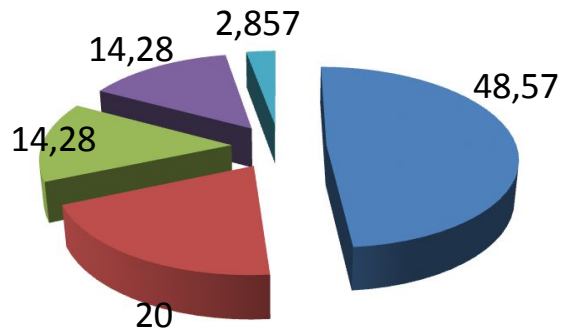

Hipertensi
DM
Jantung
Stroke
Kolesterol

Gambar 2. Pasien Hipertensi berdasarkan riwayat penyakit ditinjau dari persentase kejadian dan macam-macam penyakitnya.

Berdasarkan gambar 2, diketahui bahwa pasien hipertensi lebih banyak memiliki riwayat penyakit. Hal ini menunjukkan bahwa riwayat penyakit terdahulu pasien memiliki resiko terhadap terjadinya hipertensi. Riwayat penyakit yang diderita oleh pasien paling banyak adalah hipertensi, diikuti Diabetes Mellitus, jantung, stroke dan kolesterol. Hal ini menunjukkan bahwa hipertensi merupakan penyakit degeneratif dan dapat disebabkan oleh komplikasi dari penyakit terdahulu. Penyakit degeratif merupakan penyakit tidak menular yang berlangsung kronis [6]. Diabetes mellitus merupakan gangguan pengolahan glukosa karena kurangnya insulin dalam tubuh. Kadar glukosa yang tinggi menyebabkan konsistensi darah mengental dan menyebabkan kerja jantung semakin berat dan meningkatkan tekanan darah.

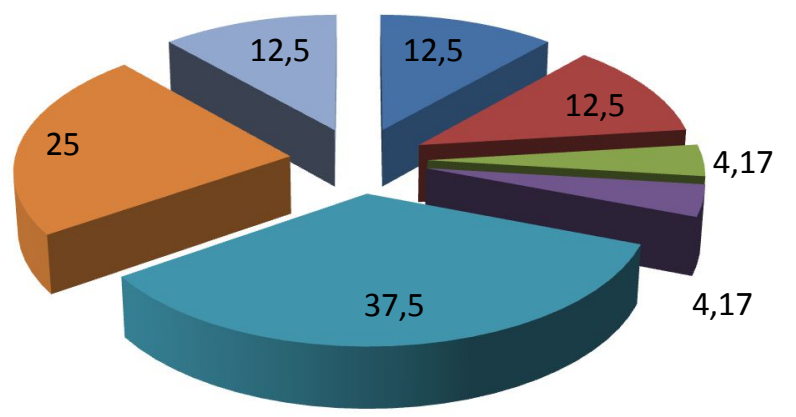

- CAD

- Cephalgia

- $\mathrm{CHF}+\mathrm{DM}$

- Dislipidemia

- Dispepsia

$\square \mathrm{DM}$

$\because$ ISK

Gambar 3. Penyakit Penyerta Pasien Hipertensi 
Gambaran pasien hipertensi berdasarkan penyakit penyerta (gambar 3). Berdasarkan gambar (3), diketahui bahwa penyakit penyerta yang paling banyak diderita oleh pasien hipertensi rawat inap adalah dispepsia. Hal ini disebabkan oleh keadaan stress pada pasien. Stress adalah kondisi ketegangan yang mempengaruhi emosional, proses berpikir dan kondisi seseorang [7]. Stres dapat menyebabkan produksi asam lambung meningkat dan mengiritasi mukosa lambung. Penyakit penyerta adalah kondisi penyakit yang dapat mengganggu terapi pengobatan pasien.

\section{KESIMPULAN}

Berdasarkan penelitian yang telah dilakukan maka dapat disimpulkan bahwa pasien hipertensi paling banyak diderita oleh pasien berusia 41-60 tahun $(58,46 \%)$, jenis kelamin perempuan $(30,76 \%)$, memiliki riwayat penyakit hipertensi $(48,57 \%)$ dan pasien dengan penyakit penyerta dispepsia $(37,5 \%)$.

\section{DAFTAR PUSTAKA}

[1] Sani, A. 2008. Hypertension Current Perspective. Medya Crea: Jakarta.

[2] Mackay J, Mensah G. 2006. The Atlas of Heart Disease and Stroke. WHO. CDC

[3] DEPKES RI. 2013. Riset Kesehatan Dasar (RISKESDA 2013): Badan Penelitian dan Pengembangan Kesehatan Kementerian Kesehatan RI Tahun 2013: Jakarta.

[4] Gunawati, R., Hartati, S dan Listiara, A. 2006. Hubungan antara Efektivitas Komunikasi Mahasiswa - Dosen Pembimbing Utama Skripsi dengan Stres Menyusun Skripsi pada Mahasiswa Program Studi Psikologi Fakultas Kedokteran Universitas Diponegoro. Skripsi

[5] Dwi, Sri Handayani., Rolan, Rusli dan Arsyik, Ibrahim. 2015. Analisis Karateristik dan Kejadian Drug Related Problems pada Pasien Hipertensi di Puskesmas Temindung Samarinda. Jurnal Sains dan Kesehatan. Vol 1 No. 2. P: $75-81$.

[6] Adianti, Handajani., Betty, Roosihermiatie dan Herti, Maryani. 2009. FaktorFaktor yang Berhubungan dengan Pola Kematian pada Penyakit Degeneratif di Indonesia. Buletin Penelitian Sistem Kesehatan. Vol. 13 No. 1. P: 42-53.

[7] Peni, Tunjungsari. 2011. Pengaruh Stress Kerja Terhadap Kepuasan Kerja Karyawan pada Kantor Pusat PT. POS (PERSERO) Indonesia Bandung. Universitas Komputer Indonesia. Vol 1. No.1. P:1-14. 